OPEN ACCESS

Edited by:

Thomas Dandekar,

University of Würzburg, Germany

Reviewed by:

Paras Jain,

Albert Einstein College of Medicine,

USA

Hiroki Iwai,

National Center for Global Health and Medicine, Japan

*Correspondence:

Jaime M. Santana jsantana@unb.br

Izabela M. D. Bastos

dourado@unb.br

tThese authors have contributed equally to this work.

Specialty section: This article was submitted to

Infectious Diseases,

a section of the journal

Frontiers in Microbiology

Received: 07 November 2016 Accepted: 20 January 2017

Published: 07 February 2017

Citation:

Portugal B, Motta FN, Correa AF, Nolasco DO, de Almeida $H$ Magalhães KG, Atta ALV, Vieira FD, Bastos IMD and Santana JM (2017)

Mycobacterium tuberculosis Prolyl

Oligopeptidase Induces In vitro

Secretion of Proinflammatory

Cytokines by Peritoneal

Macrophages.

Front. Microbiol. 8:155

doi: 10.3389/fmicb.2017.00155

\section{Mycobacterium tuberculosis Prolyl Oligopeptidase Induces In vitro Secretion of Proinflammatory Cytokines by Peritoneal Macrophages}

\author{
Brina Portugal ${ }^{1 \dagger}$, Flávia N. Motta ${ }^{1,2 t}$, Andre F. Correa ${ }^{1,3}$, Diego O. Nolasco \\ Hugo de Almeida ${ }^{1}$, Kelly G. Magalhães ${ }^{5}$, Ana L. V. Atta ${ }^{6}$, Francisco D. Vieira ${ }^{6}$, \\ Izabela M. D. Bastos ${ }^{1 *}$ and Jaime M. Santana ${ }^{1 *}$
}

\begin{abstract}
${ }^{1}$ Pathogen-Host Interface Laboratory, Department of Cell Biology, The University of Brasilia, Brasilia, Brazil, ${ }^{2}$ Faculty of Ceilândia, The University of Brasilia, Brasilia, Brazil, ${ }^{3}$ Instituto de Patologia Tropical e Saúde Pública, Universidade Federal de Goiás, Goiânia, Brazil, ${ }^{4}$ Physics Course and Postgraduate Program in Genomic Sciences and Biotechnology, Catholic University of Brasilia, Brasilia, Brazil, ${ }^{5}$ Laboratory of Immunology and Inflammation, Department of Cell Biology, The University of Brasilia, Brasilia, Brazil, ${ }^{6}$ Laboratório Central de Saúde Pública do Distrito Federal, Brasília, Brazil
\end{abstract}

Tuberculosis (TB) is a disease that leads to death over 1 million people per year worldwide and the biological mediators of this pathology are poorly established, preventing the implementation of effective therapies to improve outcomes in TB. Hostbacterium interaction is a key step to TB establishment and the proteases produced by these microorganisms seem to facilitate bacteria invasion, migration and host immune response evasion. We presented, for the first time, the identification, biochemical characterization, molecular dynamics (MDs) and immunomodulatory properties of a prolyl oligopeptidase (POP) from Mycobacterium tuberculosis (POPMt). POP is a serine protease that hydrolyzes substrates with high specificity for proline residues and has already been characterized as virulence factor in infectious diseases. POPMt reveals catalytic activity upon N-Suc-Gly-Pro-Leu-Gly-Pro-AMC, a recognized POP substrate, with optimal activity at $\mathrm{pH} 7.5$ and $37^{\circ} \mathrm{C}$. The enzyme presents $\mathrm{K}_{M}$ and $\mathrm{K}_{\mathrm{cat}} / \mathrm{K}_{M}$ values of $108 \mu \mathrm{M}$ and $21.838 \mathrm{mM}^{-1} \mathrm{~s}^{-1}$, respectively. MDs showed that POPMt structure is similar to that of others POPs, which consists of a cylindrical architecture divided into an $\alpha / \beta$ hydrolase catalytic domain and a $\beta$-propeller domain. Finally, POPMt was capable of triggering in vitro secretion of proinflammatory cytokines by peritoneal macrophages, an event dependent on POPMt intact structure. Our data suggests that POPMt may contribute to an inflammatory response during $M$. tuberculosis infection.

\footnotetext{
Keywords: tuberculosis, Mycobacterium tuberculosis, protease, serine protease, prolyl oligopeptidase, proinflammatory cytokines, molecular dynamic, fluorescence spectroscopy
}

\section{INTRODUCTION}

Despite global effort to stop tuberculosis (TB), it remains the second-deadliest infectious disease worldwide causing over 1 million deaths per year and an additional 0.4 million death resulting from TB disease among HIV-positive patients (WHO, 2015). The pathology results from a highly evolved and multifactorial ability of Mycobacterium tuberculosis, an intracellular bacterium, to 
prevent or evade effective host responses (Goldberg et al., 2014). The initial host response triggered against $M$. tuberculosis infection is characterized by innate immune response that involve the recruitment of inflammatory cells to the lungs followed by M. tuberculosis dissemination to draining lymph nodes during adaptive immune response (Chackerian et al., 2002; Reiley et al., 2008; Wolf et al., 2008). Even though M. tuberculosis can infect a variety of cell types, alveolar macrophages are its main niche. M. tuberculosis spread and dissemination is deeply correlated with its ability to infect and immunomodulate macrophages. In reaction to $M$. tuberculosis infection, macrophages upregulate effectors and signaling pathways to both prevent bacilli replication and recruit other immune cells into the site of infection (Cooper and Torrado, 2012; Sia et al., 2015). However, M. tuberculosis has an arsenal of potent mechanisms for evading those antimicrobial reactions, thereby changing the host immune response toward a pathological rather than a protective one. TB disease occurs when the pathological process overcomes the protective response, promoting chronic inflammation and lung damage leading to severe coughing, fever, and chest pains (Fogel, 2015). Although pulmonary TB is the most typical presentation of the disease, $M$. tuberculosis may also disseminate into a variety of organs causing extrapulmonary TB (Galimi, 2011).

Mycobacterium tuberculosis multidrug- (MRD) and extensively drug-resistant (XDR) strains along with HIV coinfection are recognized as predominant threats to public health and, combined to the lengthy and complex treatment for TB, they emphasize the eminent necessity to comprehend hostand pathogen-derived factors and their interactions (Roberts et al., 2013; Korb et al., 2016). Mycobacteria proteases have an active role in pathogenicity and viability of $M$. tuberculosis inside host cells (Lebrun et al., 2009; Zhao and Xie, 2011). Recently, M. tuberculosis zinc metalloprotease (zmp1), first known to be required for bacilli virulence and survival in macrophages (Master et al., 2008), was described to be implied with the endothelin system by cleavage of ET-1, which seems to be responsible for $\mathrm{TB}$ progression and inflammatory cell recruitment (Correa et al., 2014). Rv3671c (marP), an acid resistant serine-protease from $M$. tuberculosis periplasm, is responsible to maintain phagocytosed bacterial $\mathrm{pH}$ near neutrality in the acidic environment generated by IFN-gammaactivated macrophages. As a consequence, M. tuberculosis is able to resist to phagosome acidification, which is essential for M. tuberculosis virulence (Vandal et al., 2008; Zhao et al., 2015). With respect to proteolytic complex, M. tuberculosis possesses two potential ClpP proteolytic subunits (CIpP1P2) that seem to be involved in preventing the accumulation of misfolded proteins and the degradation of critical endogenous regulatory proteins. Active site mutants of CIpP1P2 showed that the enzymatic activity of each subunit is required for normal growth of $M$. tuberculosis in vitro and during infection of mice (Raju et al., 2012). Another protease already studied is Rv2224c, a cell envelope-associated predicted protease, which compromised the intracellular survival of $M$. tuberculosis into lung macrophages. Mice infected with Rv2224c mutant survived significantly longer than the wild-type infected-mice with reduced lung pathology, attenuating the virulence of
M. tuberculosis (Lun and Bishai, 2007; Rengarajan et al., 2008; Vandal et al., 2009).

This research is focused on $M$. tuberculosis prolyl oligopeptidase (POPMt) from the serine peptidase family S9, which has not been specifically investigated in mycobacteria. Prolyl oligopeptidase (POP, EC 3.4.21.26) belongs to a specific group of enzymes that is capable of hydrolyze peptide bonds on the carboxyl side of proline residues (Koida and Walter, 1976), an unusual amino acid with a cyclic structure that confers protection to proline-containing molecules from enzymatic degradation. Alterations in human POP enzymatic activity have been detected in patients suffering from depression, mania, schizophrenia, nervous anxiety, anorexia and bulimia (Maes et al., 1995, 1998, 2001), including Alzheimer's and Parkinson's diseases (Mantle et al., 1996) and multiple sclerosis (Tenorio-Laranga et al., 2010). POP seems to be related to regulation of pathways involving inositol $(1,4,5)$-triphosphate $\left(\mathrm{IP}_{3}\right)$ and it was already shown that low levels of the enzyme cause neurotrophic effects by increasing $\mathrm{IP}_{3}$ (Williams et al., 1999; Williams and Harwood, 2000; Maes et al., 2001). POP has also been studied as a potential therapeutic component for the treatment of celiac disease, a chronic enteropathy induced by immunotoxic and proline-rich gluten peptides (Shan et al., 2002).

Additionally, POP orthologous enzymes from some pathogens have been described as virulence factors of infectious diseases, as in the case of trypanosomiasis and schistosomiasis. In Trypanosoma cruzi, POPTc 80 is secreted by the infective form of the parasite and hydrolyzes extracellular matrix components such as collagen and fibronectin (Santana et al., 1997). Selective and specific POPTc80 inhibitors blocked in vitro trypomastigotes entry into different types of non-phagocytic cells reinforcing the enzyme role in cell invasion (Vendeville et al., 1999; Joyeau et al., 2000; Grellier et al., 2001; Bastos et al., 2005). POP from T. brucei is active in the plasma of infected mice and is capable of hydrolyze native collagen and peptide hormones that are deregulated in sleeping sickness (Bastos et al., 2010). More recently, POP from Schistosoma mansoni was partially characterized and it seems to be able to cleave peptides such as vasoconstrictory angiotensin I and bradykinin. This ability may provide a survival benefit to the schistosome during its residence in and movement through the venous blood system (Fajtová et al., 2015).

In this report, we identified and characterized the biochemical activity of a recombinant POP from M. tuberculosis. We also produced data about its three-dimensional structure based on molecular dynamics (MDs) experiments and investigated murine macrophages immunomodulatory response elicited by POPMt.

\section{MATERIALS AND METHODS}

\section{Bacterial Culture and Growth Conditions}

Mycobacterium tuberculosis $\mathrm{H} 37 \mathrm{Rv}$ was grown at $37^{\circ} \mathrm{C}$ in a shaking incubator $(120 \mathrm{rpm})$ in Difco ${ }^{\mathrm{TM}}$ Middlebrook $7 \mathrm{H} 9$ broth containing $0.2 \%$ glycerol, $0.05 \%$ Tween 80 , and $10 \%$ albumindextrose-catalase growth enrichment (Becton Dickinson and Company, Diagnostic Systems, Sparks, MD, USA) to $\mathrm{OD}_{600}$ of 0.5. M. tuberculosis $\mathrm{H} 37 \mathrm{Rv}$ was cultured in a BSL3 facility 
at the Laboratório Central de Saúde Pública - Brasília - DF (Lacen - DF).

\section{Cloning of popmt Gene (Rv0457c)}

The popmt gene was amplified by PCR from $M$. tuberculosis H37Rv genomic DNA using the primers: forward, $5^{\prime}$ AGATTACATATGACATTTGAGCCTGCCC-3' (Nde I site, underlined; initiation codon, bold) and reverse, $5^{\prime}$ GTTATAGGATCCTTAGCCGGCCAGCATCCG-3' (BamH I site, underlined; stop codon, bold). The 2022 bp PCR product was digested and ligated into similarly digested pET-28a $(+)$ (Novagen) using T4 DNA ligase (Invitrogen) in frame with $\mathrm{N}$-terminus 6xHis-tag vector. The cloned popmt sequence was checked by DNA sequencing of both strands using T7 primers (Genscript, USA). For overexpression of his-tagged recombinant protein, the pET-28a $(+)$ :popmt plasmid was transformed into Escherichia coli BL21 (DE3) cells.

\section{Expression and Purification of Recombinant POPMt}

Overnight culture of E. coli BL21 (DE3) carrying pET28a(+):popmt was inoculated into $500 \mathrm{ml}$ of $\mathrm{LB}$ broth supplemented with $30 \mu \mathrm{g} / \mathrm{ml}$ kanamycin and incubated at $37^{\circ} \mathrm{C}$, $200 \mathrm{rpm}$ until the $\mathrm{OD}_{600}$ reached 0.4-0.6. Standard conditions of expression were established with $0.05 \mathrm{mM}$ isopropyl $\beta$-D-1thiogalactopyranoside (IPTG) at $20^{\circ} \mathrm{C}$ for $16 \mathrm{~h}$. Recombinant POPMt (POPMt) was purified from the soluble fraction through nickel affinity chromatography (His Bind ${ }^{\circledR}$ Kit - Novagen) according to the manufacturer's protocol. Purified POPMt was stored in $50 \%$ glycerol at $-20^{\circ} \mathrm{C}$. POPMt purification was analyzed on $10 \%$ SDS-PAGE followed by Coomassie Brilliant Blue $\mathrm{R}$ staining (Sigma-Aldrich). The protein was quantified using the molar absorption coefficient $\varepsilon$ value of 148,865 $\left(\mathrm{M}^{-1} \mathrm{~cm}^{-1}\right)$ at $280 \mathrm{~nm}$ measured in water.

\section{Western Blot}

The membrane was blocked by incubation in $5 \%(\mathrm{w} / \mathrm{v})$ nonfat milk/PBS overnight at $4^{\circ} \mathrm{C}$. Blot was incubated for $2 \mathrm{~h}$ with 1:100 POPMt diluted in 1\% non-fat milk/PBS. After several washes with PBS, the membrane was incubated for $1 \mathrm{~h}$ with 1:1000 alkaline phosphatase-conjugated goat antimouse IgG (Invitrogen). Immunocomplexes were revealed with the alkaline phosphatase substrate 5-bromo-4-chloro-3indolyl-phosphate/Nitro Blue Tetrazolium (BCIP/NBT Color Development Substrate - Promega).

\section{Enzymatic Characterization of POPMt}

Recombinant POPMt enzymatic activity was measured using 7-amido-4-methylcoumarin (AMC). The released of AMC was monitored up to $20 \mathrm{~min}$ in 96-well SpectraMax M5 microplate reader (Molecular Devices) at $25^{\circ} \mathrm{C}$ as previously described (Grellier et al., 2001). The POPMt enzymatic activity was assayed on several AMC-containing substrates: AlaAla-Phe-AMC, L-Proline-AMC hidrobromide, N-Succinyl-IleAla-AMC, N-Succinyl-Leu-Tyr-AMC, N-Succinyl-Leu-Leu-
Val-Tyr-7-AMC, L-Leucine-AMC hydrochloride, Gly-ProAMC, N-Succinyl-Gly-Pro-AMC (N-Suc-Gly-Pro-AMC) and $N$-Succinyl-Gly-Pro-Leu-Gly-Pro-AMC （N-Suc-Gly-Pro-LeuGly-Pro-AMC), which were purchased from Sigma-Aldrich. Enzymatic reactions were performed with $25 \mathrm{mM}$ Tris $\mathrm{pH} 7.5$ (reaction buffer) containing $20 \mu \mathrm{M}$ of fluorogenic substrate with or without additives $(\mathrm{NaCl}-0$ to $400 \mathrm{mM}$ and DTT -0 to $20 \mathrm{mM}$ ) in $100 \mu \mathrm{l}$ final volume. The temperature assay was carried out by incubating the enzyme at different temperatures: $20,28,37,40,45,60$, or $80^{\circ} \mathrm{C}$ for $20 \mathrm{~min}$ and afterward $20 \mu \mathrm{M}$ of substrate were added. The $\mathrm{pH}$ activity optimum of POPMt was determined in AMT buffer (100 mM acetic acid, $100 \mathrm{mM} \mathrm{MES}$, and $200 \mathrm{mM}$ Tris- $\mathrm{HCl}$ ) at $\mathrm{pHs}$ ranging from 5.0 to 10.0 (Bastos et al., 2010). All experiments were performed in triplicate and repeated three times independently.

Kinetic parameters were determined by incubation of POPMt in reaction buffer with different concentrations $(6.25-150 \mu \mathrm{M})$ of N-Suc-Gly-Pro-Leu-Gly-Pro-AMC. $K_{m}$ and $V_{\max }$ were determined by hyperbolic regression according to CornishBowden (Cornish-Bowden, 1976). The $k_{\text {cat }}$ was calculated by $=V \max /[\mathrm{E}] \mathrm{t}$, where $[\mathrm{E}]_{t}$ is the total enzyme concentration.

Different concentrations of the inhibitors tosyllysylchloromethane (TLCK), N-p-Tosyl-L-phenylalanine chloromethyl ketone (TPCK), bestatin, EDTA, L-transepoxysuccinylleucylamido-(4-guanidino) butane (E-64), 1,10-phenanthroline and leupeptin (0.01-100 nM) were incubated with POPMt in $100 \mu \mathrm{l}$ reaction buffer for $15 \mathrm{~min}$ at room temperature before the addition of $20 \mu \mathrm{M} \mathrm{N}$-Suc-Gly-ProLeu-Gly-Pro-AMC. The enzymatic reactions were monitored as described above. The inhibition profile $\left(\mathrm{IC}_{50}\right)$ using Z-ProProlinal, a specific inhibitor of POPs, was determined by non-linear regression analysis from the residual activity versus inhibitor concentrations curve and the $K i$ values determined using the Cheng-Prusoff method $K_{i}=\mathrm{IC} 50 /[1+([S] / \mathrm{Km})]$, where $[\mathrm{S}]$ is the concentration of the substrate (Yung-Chi and Prusoff, 1973).

\section{Fluorescence Spectroscopy}

Fluorescence measurements were performed using an ISS K-2 (Champaign, IL, USA) spectrofluorimeter at the same temperatures used in activity assay as described above. Spectra were recorded from 305 to $450 \mathrm{~nm}$ using an excitation wavelength of 295 and $2 \mathrm{~nm}$ bandwidth for both excitation and emission. Solutions of $0.30 \mu \mathrm{M}$ POPMt were prepared in AMT buffer at $\mathrm{pHs}$ ranging from 5 to 10 . Measurements were carried out in a $1.0 \times 1.0-\mathrm{cm}$ cuvette. The final spectra were baseline corrected by subtracting buffer spectrum.

\section{Homology Modeling and Molecular Dynamics Simulation Parameters}

The POPMt 3D-model was built based on the Myxococcus xanthus POP crystal structure, PDB code 2BKL (Shan et al., 2005), using the MODELLER 9v8 software (Eswar et al., 2006). Briefly, using the NCBI BLASTP webservers (Altschul et al., 1997), the POPMt sequence was submitted to a search query against a structure database [Protein Data Bank (PDB) 
(Berman et al., 2000)]. The PSI-BLAST algorithm was used to perform an alignment profile between all the homologous sequences and facilitate the alignment between the target sequence (POPMt) and the template. The alignment was then subjected to the MODELLER software, resulting in 5 comparative models. The one with the lowest DOPE score was selected to further refinements by MDs simulations.

The MD simulation was performed using the computational package GROMACS 4 - Groningen Machine for Chemical Simulations (Hess et al., 2008). The simulated ensemble was composed of the POPMt model immersed in 14,46 Single Point Charge (SPC) water molecules (Berendsen et al., 1981) in a cubic box with edges of $77 \AA$. Four sodium atoms were also included in order to neutralize the system charges. The lysine residues of the protein were protonated and an amide group was added to the C-terminus. The SETTLE algorithm was used to constrain the geometry of water molecules, and the LINCS (Hess et al., 1997) algorithm was used to constrain bond lengths. The electrostatic corrections were performed by the Particle Mesh Ewald (PME) algorithm with a cutoff radius of $1.4 \mathrm{~nm}$, in order to minimize the computational time of the simulation. Derived from the Ewald summation, PME estimates in the Fourier space the long-range interactions that happen in real space (Darden et al., 1993; Essmann et al., 1995). The same radius value cutoff was also used in the van der Waals interactions. The neighbors list of each atom was updated every 10 simulation steps of $20 \mathrm{fs}$ each.

The system was contained. Two steps of energy minimization were performed (2 ns each), the first used the conjugate gradient algorithm and the other one used the steepest descent algorithm. After the energy minimization step, the system went through a pressure and temperature normalization process using the integrator stochastic dynamics (SD), also for $2 \mathrm{~ns}$. Thereafter, the system went through a position restrain step using the MDs integrator for another 2 ns. This ensemble was subjected to a relaxation MDs run at GridUNESP computers. The $50 \mathrm{~ns}$ simulation was divided into 25,000,000 steps of $2 \mathrm{fs}$ each.

\section{Stimulation of Peritoneal Macrophages with POPMt In vitro}

Peritoneal macrophages from naive C57BL/6 mice were harvested by lavage with sterile Roswell Park Memorial Institute (RPMI) 1640 medium. Macrophages $\left(10^{6}\right.$ cells $\left./ \mathrm{mL}\right)$ were cultured overnight in RPMI containing $2 \%$ fetal calf serum. Non-adherent cells were removed after phosphate-buffered saline (PBS) wash. Macrophages were stimulated with POPMt (0.01-10 $\mathrm{mg} / \mathrm{mL})$, either native or denatured by boiling, for $24 \mathrm{~h}$ at $37^{\circ} \mathrm{C}$ in $\mathrm{CO}_{2}$ atmosphere. Macrophages viability assessed by trypan blue exclusion at the end of each experiment was always $>95 \%$.

\section{Immunomodulatory Properties of POPMt}

Cell-free supernatants from in vitro POPMt stimulated macrophages were collected after $24 \mathrm{~h}$ and stored at $-20^{\circ} \mathrm{C}$ until analysis. TNF- $\alpha$, IL-6, IL-12p70, IL-23, IL-10, IL-1b, and MCP-1 levels were measured in supernatants from in vitro POPMt stimulated macrophages by enzyme-linked immunosorbent assay, in accordance with manufacturer instructions (R\&D Systems).

\section{Statistical Analysis}

Bars graphics were generated with Prism software (GraphPad). All data was expressed as mean and standard deviation. Statistical analyses were performed by ANOVA followed by the NewmanKeuls-Student and Student's $t$-tests. The significance level was set at $p<0.05$.

\section{RESULTS}

\section{Expression and Purification of POPMt}

The popmt gene from $M$. tuberculosis has an open read frame of $2,022 \mathrm{bp}$ and encodes a protein of 673 amino acids residues with predict molecular mass of $74.40 \mathrm{kDa}$. POPMt has about 65 and $78 \%$ identity compared to $M$. smegmatis and M. avium POPs, respectively. On the other hand, POPMt amino acid sequence identity compared to human POP is about $24 \%$. POPMt was expressed in E. coli BL21(DE3) as a soluble and active enzyme which allowed us to proceed to its purification (Figure 1A) and biochemical characterization. When subjected to intra-dermal immunization, isogenic BALB/c yielded specific anti-POPMt serum capable of recognizing a single band of approximately 75 $\mathrm{kDa}$ in the total extract of $M$. tuberculosis proteins. This result confirms that POPMt is immunogenic in mice and is expressed in H37Rv, a M. tuberculosis human pathogenic strain (Figure 1B).

\section{Substrate Specificity and Kinetic Parameters of POPMt}

Some fluorogenic peptides were used to define the substrate specificity of POPMt (Table 1). Among these substrates, the enzyme cleaved specifically at the carboxyl terminus of proline residues, feature similar to other POP, which are known to cleave a Pro-Xaa bond in peptides, where Xaa is not a proline residue
A

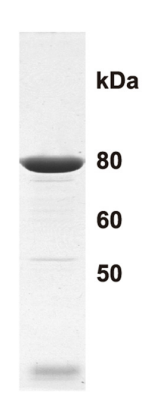

B

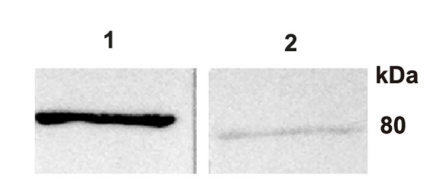

FIGURE 1 | Purification and analysis of the recombinant and native POPMt. (A) POPMt was produced in Escherichia coli BL21(DE3), purified on nickel-agarose resin and evaluated by comassie-stained 10\% SDS-PAGE. (B) Mycobacterium tuberculosis total protein extract was resolved by $10 \%$ SDS PAGE and transferred to nitrocellulose membrane. Blot was probed with anti-POPMt. (1) POPMt purified; (2) M. tuberculosis H37Rv total protein extract. 
TABLE 1 | POPMt substrate specificity.

\section{Substrate}

Relative activity (\%)

Ala-Ala-Phe-AMC

L-Proline-AMC

Gly-Pro-AMC

$N$-Succinyl-Ile-Ala-AMC

$N$-Succinyl-Leu-Tyr-AMC

$N$-Succinyl-Leu-Leu-Val-Tyr-AMC

L-Leucine-AMC

N-Succinyl-Gly-Pro-AMC

$\mathrm{N}$-Succinyl-Gly-Pro-Leu-Gly-Pro-AMC

n.a, no activity. Assays were performed by incubating $300 \mathrm{ng}$ of POPMt with $20 \mu \mathrm{M}$ of each substrate. Substrate hydrolysis was recorded up to $20 \mathrm{~min}$.

(Koida and Walter, 1976). With respect to these substrates, the enzyme was active on $N$-Suc-Gly-Pro-Leu-Gly-Pro-AMC and $\mathrm{N}$-Suc-Gly-Pro-AMC but totally inactive toward L-Pro-AMC and Gly-Pro-AMC. The $\mathrm{K}_{\mathrm{M}}$ and $\mathrm{K}_{\mathrm{cat}} / \mathrm{K}_{\mathrm{M}}$ values of POPMt toward $N$-Suc-Gly-Pro-Leu-Gly-Pro-AMC were $108 \mu \mathrm{M}$ and $21.83 \mathrm{mM}^{-1} \mathrm{~s}^{-1}$, respectively.

\section{Effects of $\mathrm{NaCl}$ and DTT on POPMt Catalysis}

Thiol-reacting reagents and salts are known to improve POP enzymatic activity (Usuki et al., 2009). Based on that, $\mathrm{NaCl}$ and DTT were added into buffer reaction to determine their influence on POPMt enzymatic activity. As shown in Figure 2A, up to $20 \mathrm{mM}$ DTT did not affect the enzyme activity. As for DTT, increasing concentrations of $\mathrm{NaCl}$ (up to $400 \mathrm{mM}$ ) did not alter POPMt enzymatic activity toward N-Suc-Gly-Pro-Leu-Gly-ProAMC (Figure 2B).

\section{Influence of pH and Temperature on POPMt Structure and Enzymatic Activity}

The characterization of POPMt revealed that the enzyme had a strong dependence on slightly alkaline $\mathrm{pH}$ 7.0-8.5. It was most stable at $\mathrm{pH} 7.5$ and retained more than $90 \%$ of the residual activity at $\mathrm{pH} 8.0$ and 8.5 (Figure 3A).
We also analyzed POPMt tertiary structure changes under different $\mathrm{pHs}$ by fluorescence spectroscopy (Figure 3B). It is possible to observe changes in emission spectra of tryptophan in response to protein conformational transitions, subunit association, substrate binding or denaturation, all of which can affect the local environment surrounding the tryptophan indole ring (Lakowicz, 2004). POPMt contains 20 tryptophan residues and, as shown in Figure $\mathbf{4 B}$, the emission maximum was $335 \mathrm{~nm}$, indicating that most POPMt tryptophans are partially buried in the protein. The shape of the enzyme intrinsic fluorescence spectra did not change from $\mathrm{pH} 7.5$ to 8.5 and a limited red-shift happened at $\mathrm{pH} 9.0$ and 10.0 .

The effect of temperature on the enzymatic activity of POPMt was examined over a range of $20-80^{\circ} \mathrm{C}$ at $\mathrm{pH} 7.5$. The enzyme showed maximal enzymatic activity between 20 and $37^{\circ} \mathrm{C}$. While at $45^{\circ} \mathrm{C}$, the enzyme activity decreased nearly $50 \%$ (Figure 4A). As for $\mathrm{pH}$ analysis, we also applied the tryptophan residue fluorescence as a reporter for structural changes under different temperatures and, according to all the adjusted spectra, temperatures up to $60^{\circ} \mathrm{C}$ did not alter tryptophan emission pattern (Figure 4B).

\section{Specificity of POPMt Enzymatic Activity Inhibition}

Table 2 summarizes the effects of protease inhibitors on the enzymatic activity of POP from $M$. tuberculosis. Although POPMt is a serine protease, its activity was partially inhibited by AEBSF and TLCK, 33 and 35\%, respectively. On the other hand, TPCK, a chymotrypsin-like protease inhibitor, inhibited $66 \%$ of the enzyme activity. Leupeptin, E64, pepstatin A and metalloproteinase inhibitors such as $o$-phenanthroline, bestatin and EDTA had no effect on the enzyme activity. The canonical POP inhibitor Z-Pro-Prolinal (Wilk and Orlowski, 1983; Yoshimoto et al., 1987) was also assayed on POPMt, showing a $K i$ value of 16.87 nM. Z-Pro-Prolinal was a less efficient inhibitor when compared to mouse and human POPs with $K i$ value of 0.35 and $0.50 \mathrm{nM}$, respectively (Bakker et al., 1990).
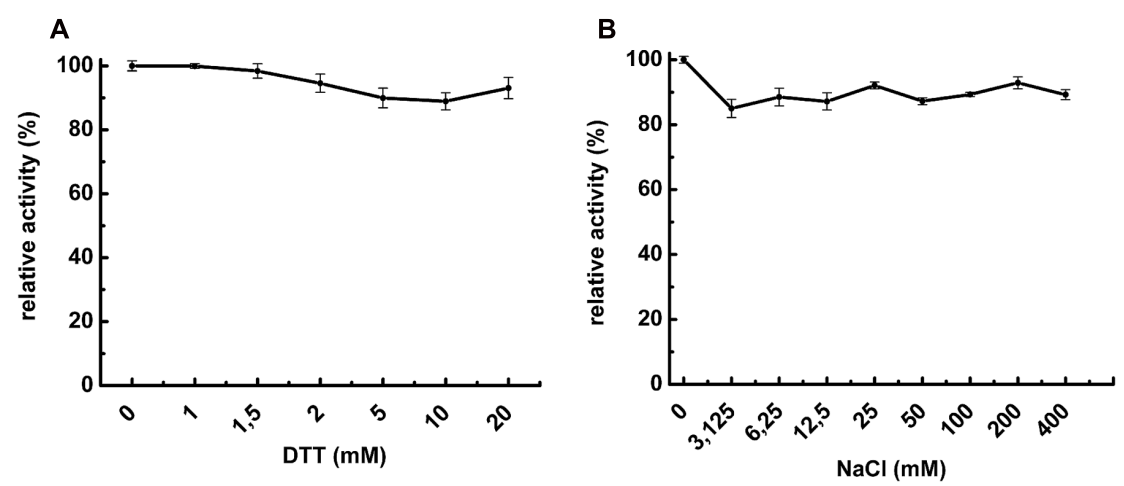

FIGURE 2 | Effects of additives on POPMt enzymatic activity. The substrate N-Suc-Gly-Pro-Leu-Gly-Pro-AMC was hydrolyzed by POPMt in the presence of (A) 0-20 mM DTT; (B) 0-400 mM NaCl. Results are expressed as the percent activity relative to the maximum value obtained at each condition. 

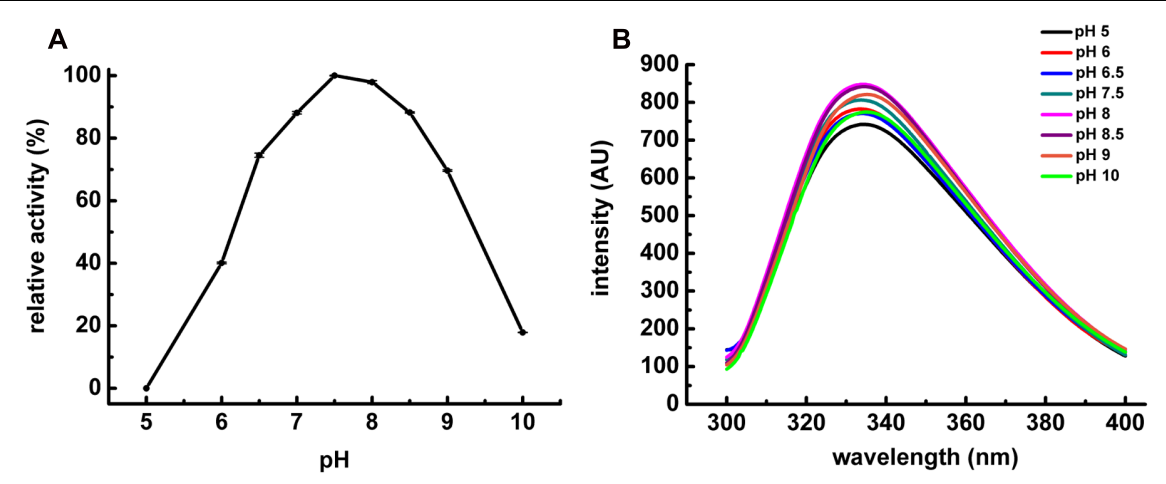

FIGURE 3 | pH influence on POPMt enzymatic activity and POPMt tertiary structure. (A) pH optimum enzymatic activity of POPMt was assayed in AMT buffer against $\mathrm{N}$-Suc-Gly-Pro-Leu-Gly-Pro-AMC. Results are expressed as the percent activity relative to the maximum value obtained at each condition. (B) Intrinsic spectra were recorded at $25^{\circ} \mathrm{C}$ from 305 to $400 \mathrm{~nm}$ using excitation wavelength of $295 \mathrm{~nm}$ at different pHs.
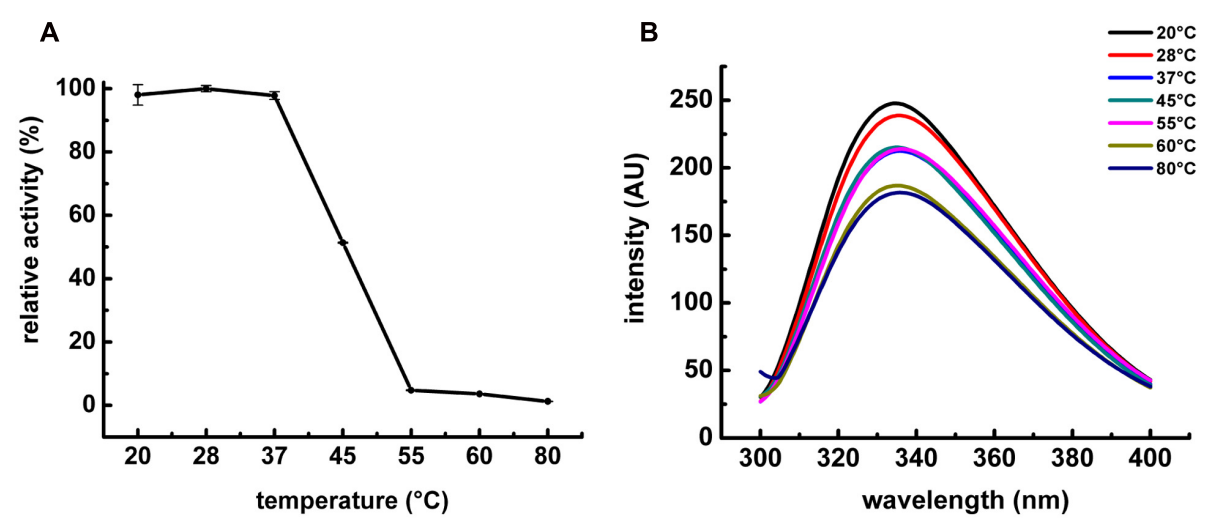

FIGURE 4 | Influence of temperature on POPMt enzymatic activity and POPMt tertiary structure. (A) POPMt was incubated with substrate at different temperatures for $20 \mathrm{~min}$ and the release of AMC was quantified as described in Section "Materials and Methods." Results are expressed as the percent activity relative to the maximum value obtained at each condition. (B) Intrinsic spectra were recorded from 305 to $400 \mathrm{~nm}$ using excitation wavelength of $295 \mathrm{~nm}$ at different temperatures.

\section{POPMt Homology Modeling and Molecular Dynamics Simulations}

Concerning the homology modeling, the top ranked homolog structure returned by BLAST was that of $M$. xanthus (PDB ID $2 \mathrm{BKL}$ ), with a query coverage of 64 and $37 \%$ identity. As we could not obtain higher query coverage, we opted to perform MDs simulations to both refine and validate our model. We predicted that an equilibrium MDs simulation would allow a relaxation of the macromolecule, in which the POPMt features would be adopted instead of those from $M$. xanthus enzyme.

The POPMt macromolecular structure is divided in two domains with a catalytic $\alpha / \beta$ hydrolase domain and a $\beta$-propeller domain (Figure 5A). The propeller domain is based on a radially arranged seven-fold repeat of four stranded antiparallel $\beta$ sheets. In the case of POPs, this domain is considered to be of the "open-velcro" topology, where first and seventh blades are connected only through hydrophobic interactions, although their primary sequences diverge (Kaushik and Sowdhamini, 2011). The POPMt catalytic triad residues (Ser 532, Asp 615, e His 647) position is conserved like in other POPs and
TABLE 2 | Inhibition of POPMt by protease inhibitors.

\begin{tabular}{lcc}
\hline Inhibitor & Concentration $(\mathbf{m M})$ & Inhibition (\%) \\
\hline AEBSF & 1 & 33 \\
Bestatin & 0.1 & $\mathrm{n} . \mathrm{i}$ \\
E-64 & 0.1 & $\mathrm{n} . \mathrm{i}$ \\
EDTA & 1 & $\mathrm{n} . \mathrm{i}$ \\
Leupeptin & 0.1 & $\mathrm{n} . \mathrm{i}$ \\
Pepstatin A & 0.1 & $\mathrm{n} . \mathrm{i}$ \\
Phenanthroline & 0.1 & $\mathrm{n.i}$ \\
TLCK & 0.1 & 35 \\
TPCK & 0.1 & 66
\end{tabular}

n.i, no inhibition. Assays were performed by incubating 300 ng of POPMt with the inhibitor for $15 \mathrm{~min}$, before the addition of $20 \mu \mathrm{M}$ of substrate. Substrate hydrolysis was recorded up to $20 \mathrm{~min}$.

it is localized at the interface of the catalytic and propeller domains (Figure 5B) (Rea and Fülöp, 2006). The amino acid sequence of POPMt with the assigned secondary structure comprising coil, $\beta$ sheet, $\alpha$ helix and Pi helix is shown in Figure 5B. 
A

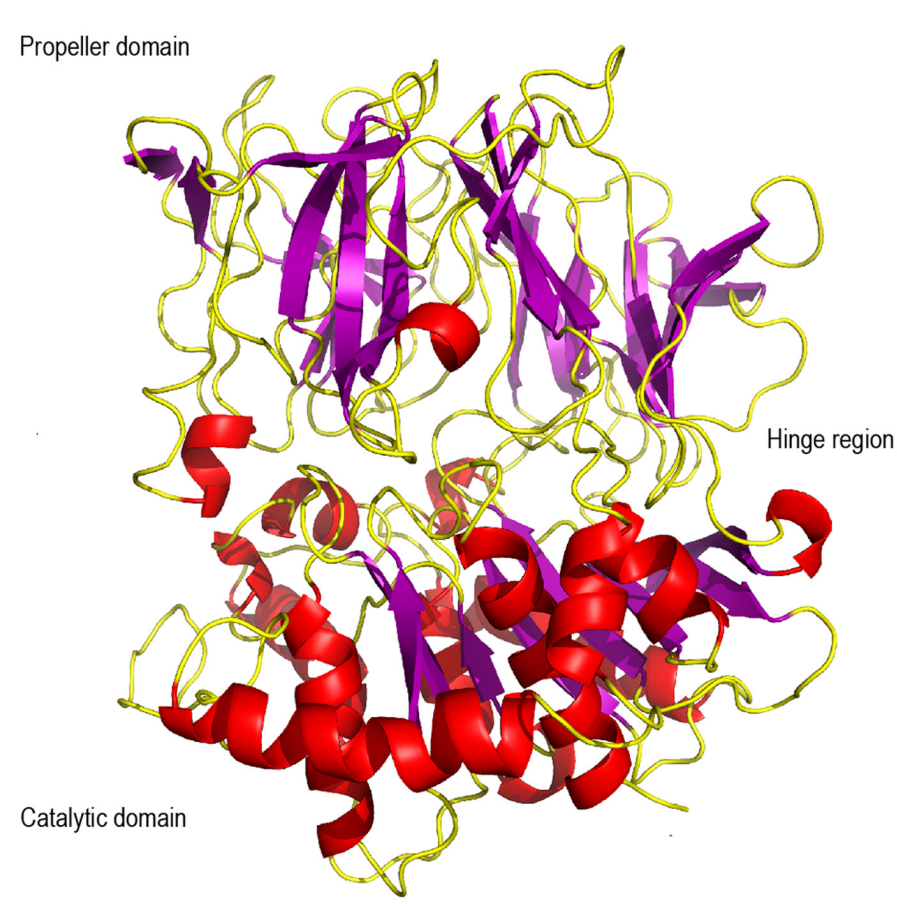

B

POPMt $\quad \overrightarrow{\text { MTFEPAPDGADPYLWLEDVTGAEALDWVRA }} 30$ RNKPTTAAFCDAEFERMRVEALEVLDTDARIPYVNRRGNY LYNFWRDAANPRGLWRRTTLDSYRTDSPGWDVLIDVDELG ${ }_{\text {RADDQKWVWGGAGVIEPDYTRALIGLSPGGSDASIVREFD }}$ $\overrightarrow{\text { MLTREFVEDFQLPPAKSQITWEDPTVLLGTDFGDST }}$ TSGYPRVIKRWRRGKLADAETIFEGAGTDVRVNASADRT $\overrightarrow{\text { PGFERTLLGRALDWNEEVYLRGELIRIEAPTDASVSI }} 270$ HRDWLLIELRTDWTVATTRYTAGSLLAEYDEFLAGSAEL 310 QVVVEPDEHTALYQYAWTRDRLLIVTLADVASRVEIATPG SWRREPLGIPAATNTVIVSADSHGDEFFDSSGFDTPSR $\overrightarrow{L M R G D D G R L A E I K S A P A F F D A E N M A V T Q Y F A T S D D G T S I ~}_{430}$ $\overbrace{\text { PYFVVRRTDADNPGPTLLNGYGGFETSTPTYDGVLGRLW }} 470$ LARGGTYALAN IRGGGEYGPGWTQAMREGRDKVADFAA 510 VATDLVTRGITTAEQLGARGSNGGLLGIMLTGYPEKG 550 ALVCDVPLLDMKRYHLLAGASWMAEYGDPDNPDDWKFIS 590 EYSPYQN ISANRKYPPVLMTTSTRDDRVHPGHARKMTAAL 630 QAAGHPVWYYEN IEGGHAGAADNAQ IAFKSALSFAFLWRM 670 $\overline{L A G} \quad 673$

FIGURE 5 | Sequence and three dimensional structure of POPMt. (A) POPMt tertiary structure showing $\alpha / \beta$ hydrolase catalytic domain, $\beta$-propeller domain and the hinge region between the two domains. (B) The amino acid sequence of POPMt with the assigned secondary structure: coil (black line), $\beta$ sheet (yellow), $\alpha$ helix (red), Pi helix (green). Catalytic site is highlighted in cyan.

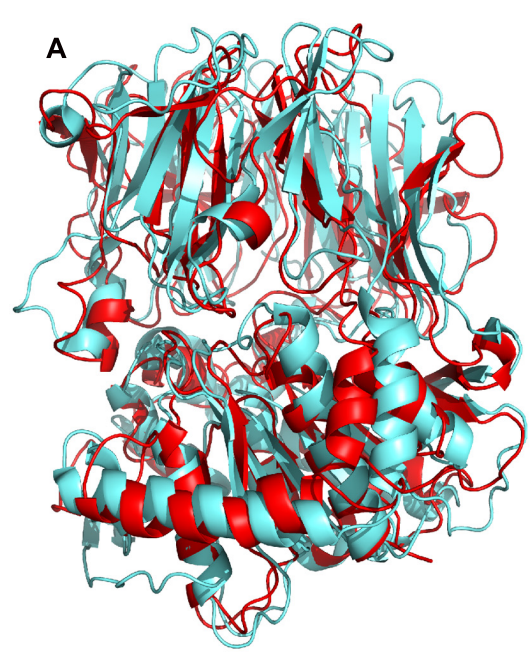

B

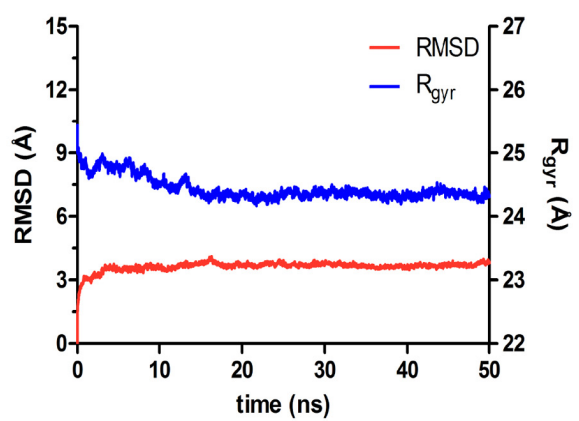

FIGURE 6 | POPMt 3D model comparison and stability during the molecular dynamics simulation. (A) Superposition of the POPMt 3D model after MD simulations (cyan) and the POPMx crystallographic structure (red). (B) Root-mean square deviation analysis of the trajectory frames (RMSD, red line, left y axis) indicates that the model achieved structural stability after $5 \mathrm{~ns}$ of simulation. The decrease of the radius of gyration over simulation time (Rgyr, blue line, right y axis) corroborates the stability hypothesis, suggesting that the protein has become more compact at the end of the simulation. 
A

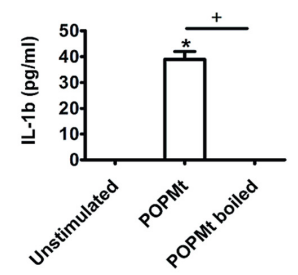

C

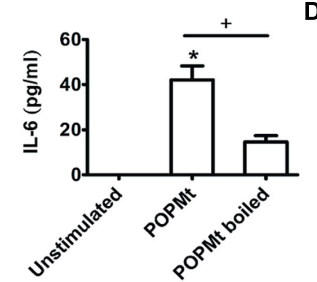

E

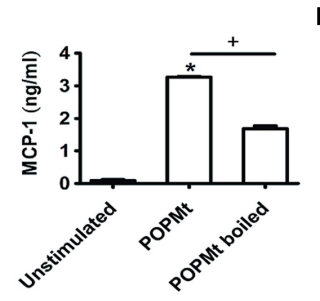

G

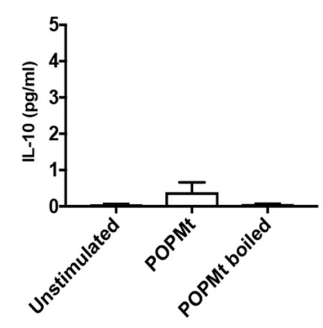

FIGURE 7 | Immunomodulation triggered by POPMt. Peritonial macrophages were stimulated with either intact or boiled POPMt for $24 \mathrm{~h}$ in vitro. Levels of (A) IL-1b, (B) IL-12p70, (C) IL-6, (D) TNF- $\alpha$, (E) MCP-1, (F) IL-23, and (G) IL-10 were analyzed from the supernatant cultured. Statistical significances $(p<0.05)$ between intact and boiled enzymes are represented by the symbol + . Unstimulated versus intact enzyme are represented by the symbol *.

The superposition of the predicted and template structures (Figure 6A) shows an average RMSD of $4.86 \AA$ (Figure 6B, red line). This might be explained by the fact that the $M$. xanthus POP template is a crystal structure, hardened due to the compression inherent in the crystallization process, which results in the inability of structure accommodation and its respective adaptation to the environment. Structures subjected to MDs simulations are expected to exhibit RMSD changes, as they go through a process of relaxation and adjustments, always driven by biochemical and structural restrictions.

Albeit resulting in conformational changes when compared to the initial structure, as observed by the RMSD shift, the POPMt relaxation process led the structure to a smaller radius of gyration (Figure 6B, blue line), indicating the contraction of the system. This can be interpreted as a sign of conformational stability, as during protein unfolding we would expect the opposite, and may be explained due to the increasing number of intramolecular hydrogen bonds during the simulation (Supplementary Figure S1). This kind of interactions cooperates to reduce the volume of the system and thus increase the degree of compactness of the protein.

Another sign of compactness is the solvent accessible area (Supplementary Figure S1), which corresponds to the area of solvent removed due to the relationship of the protein with itself. By folding, the protein contracts, resulting in the reduction of the solvent accessible area, decreasing the protein volume characterized by the separation of hydrophobic and hydrophilic portions.

Data extracted from this MD trajectory will be applied to identify clusters of conformational families as recently accomplished to the Dengue virus NS3 protease (de Almeida et al., 2013), which will be used in ensemble docking campaigns aiming the identification of new drug-like hits against POPMt.

\section{POPMt Induces Proinflammatory Cytokine Production In vitro}

To investigate the immunomodulatory properties of POPMt in triggering immune responses in vitro, peritonial macrophages were stimulated with purified POPMt for $24 \mathrm{~h}$. POPMt significantly triggered production of the proinflammatory cytokines TNF, IL-12p70, IL-6, IL-23 and IL-1b, as well as chemokine MCP-1 after 24 h (Figures 7A-F). However, POPMt failed to trigger the anti-inflammatory and immunosuppression cytokine IL-10 (Figure 7G). In addition, all analyzed cytokines and chemokine secretion induced by POPMt were dependent on the enzyme intact structure since cytokine and chemokine production induced by boiled POPMt were greatly reduced.

\section{DISCUSSION}

Here we report, for the first time, the identification, purification, biochemical characterization and some immunomodulatory features of a POP from M. tuberculosis. POPs have already been described in bacteria like Flavobacterium meningosepticum (Yoshimoto et al., 1980, 1991), Sphingomonas capsulate (Kabashima et al., 1998), Aeromonas hydrophila (Kanatani et al., 1993), and M. xanthus (Shan et al., 2004).

Enzymatic tests were performed using N-Suc-Gly-Pro-LeuGly-Pro-AMC as substrate since it was hydrolyzed more efficiently than the others tested. This result was also observed for POP from T. cruzi and T. brucei (Santana et al., 1997; Bastos et al., 2010). The additives used in this study (DTT and $\mathrm{NaCl}$ ) are known to influence the enzymatic activity of POP family, however, such effect was not observed for POPMt. Nevertheless, the insensitivity to thiol-reacting reagents, such as DTT, has been reported for other members of POP family. For example, DTT did not interfere in the enzymatic activity 
of oligopeptidase B from T. cruzi (Motta et al., 2012) neither in POP from F. meningosepticum and Lyophyllum cinerascens (Yoshimoto et al., 1988, 1991). Oligopeptidase B from T. brucei has a Cys residue located at position 256 that was identified as the one responsible for interaction with thiol reagents (Morty et al., 2005). It also has been shown that porcine brain POP is inhibited by $\mathrm{pCMB}$, a cysteine protease inhibitor, possibly by its reaction with $\mathrm{Cys}_{256}$, a residue located close to the enzyme substrate binding site (Szeltner et al., 2000). Based on our model, the two Cys residues predicted in POPMt primary sequence (Cys40 and Cys554) are not located near the catalytic site. Moreover, according to our MD studies, the distance between these POPMt Cys residues remained at approximately $17 \AA$ throughout the simulation, such distance is not favorable for formation of a disulfide bridge, which is postulated between 4.4 and $6.8 \AA$ (Richardson, 1981). Both features may explain the insensitivity of POPMt to thiol reagents.

POPMt optimum $\mathrm{pH}$ and temperature is at 7.5 and $37^{\circ} \mathrm{C}$, respectively. These values are compatible with those already described for other POPs (Yoshimoto et al., 1980; Szwajcer-Dey et al., 1992). Fluorescence spectroscopy has been widely used in structural and functional studies of proteins. The intrinsic fluorescence of the tryptophan residues of proteins is a natural sensitive probe for protein denaturation and can be used in experiments of protein tertiary structure (Lakowicz, 2004). These approaches have already been used to probe into the tertiary structure unfolding of two carbonic anhydrase, Rv3588c and Rv1284, both from M. tuberculosis (Mukherjee et al., 2009). The spectra of POPMt tryptophan fluorescence did not alter the maximum emission wavelength in response to changes in $\mathrm{pH}$, suggesting that POPMt preserved a similar degree of structure folding throughout the experiment. Notably, POPMt unfolding was minimum when temperature increased. The maximum emission intensity for POPMt decreased following temperature increasing and, on the other hand, the maximum emission wavelength did not (red)shift, suggesting, as for $\mathrm{pH}$, a similar degree of structure folding. Even though it appears that POPMt tertiary structure is stable regarding to $\mathrm{pH}$ and temperature changes, it is necessary to take into account that this enzyme contains 20 tryptophan residues, which could influence their utilization as reporter groups in studying protein (un)folding (Pokalsky et al., 1995).

Extracellular matrix constituent destruction is critical to the success of $M$. tuberculosis infection, but the essential mechanisms of this destruction remain poorly understood. It has been mainly proposed that host matrix metalloproteinases (MMPs) play a central role in the event, owing to their unique ability to degrade fibrillar collagens and other matrix components (Elkington et al., 2011). Besides tissue damage, collagen fragmentation may generate active peptides named matrikines, which have been implicated in immune response by altering cellular migration and chemotaxis (Wells et al., 2015). Emerging evidences has suggested that POPs could participate in the inflammatory response through the modulation of active peptides (Gaggar et al., 2010; Tenorio-Laranga et al., 2013, 2015). For instance, in concert with MMPs, POP is responsible for generation of one type of matrikine, the tripeptide PGP (proline-glycineproline), a neutrophil chemoattractant that has been implicated in inflammation and disorders of the respiratory system (O'Reilly et al., 2009).

Inflammatory cytokines such as IFN $\gamma$, mainly secreted by $\mathrm{T}$ lymphocytes, could activate macrophage antimicrobial mechanisms against $M$. tuberculosis. Moreover, $\mathrm{TNF} \alpha$ is a crucial proinflammatory cytokine for $M$. tuberculosis control in humans and in experimental animals (Solovic et al., 2010), by contributing to activation of macrophages for killing of intracellular mycobacteria and to modulate apoptosis of infected cells (Balcewicz-Sablinska et al., 1998; Clay et al., 2008). Unlike $\mathrm{TNF} \alpha, \mathrm{IL}-6$ is critical to resistance against M. tuberculosis, but it is dispensable for the control of mycobacterial growth after low-dose aerosol-delivered infection (Sodenkamp et al., 2012). Despite its importance in mediating inflammation, IL-6 is not as essential as TNF $\alpha$ for antimycobacterial effector mechanisms (Ladel et al., 1997; Saunders et al., 2000; Nagabhushanam et al., 2003; Martinez et al., 2013). Another important macrophage produced proinflammatory cytokine essencial to $M$. tuberculosis killing is IL-1 $\beta$, which can also regulate Th17 cytokines secretion. Mice that lack IL-1 $\beta$ or its receptor are highly susceptible to $M$. tuberculosis infection, and IL-1 $\beta$ directly inhibits M. tuberculosis intracellular growth (Jayaraman et al., 2010, 2013; Mayer-Barber et al., 2010; Qiu et al., 2012; SadaOvalle et al., 2012). Here, we have showed that POPMt is capable of immunomodulating murine macrophages by inducing the secretion of the proinflammatory Th1 cytokines TNF $\alpha$, IL- $1 \beta$, IL-6, IL-12, as well as the Th17 IL-23 in murine macrophages, indicating that POPMt could significantly contribute to TB immunopathology.

Mycobacterium tuberculosis infection is also characterized by induction of elevated levels of a variety of chemokines, such as CXCL-8, MCP-1, MCP-3, MCP-5, RANTES, MIP1- $\alpha$, MIP1- $\beta$, MIP-2 and IP-10 and their receptors (Orme and Cooper, 1999; Juffermans et al., 2000; Mihret et al., 2013). Our data demonstrated that POPMt induced high levels of MCP-1 secretion, suggesting that it could be critical in monocyte/macrophage recruitment process. Beyond monocyte/macrophage recruitment, these inflammatory chemokine recruit additional cells from the blood compartment (Gerszten et al., 1999) and from other areas of the lung (Sertl et al., 1986; Holt and Schon-Hegrad, 1987) to amplify the inflammatory response. In addition, MCP-1 is associated with the immune response to $M$. tuberculosis infection, as MCP-1 deficient mice had early and persistent defects on macrophage recruitment to the lungs and a reduced number of macrophage and dendritc cells in mediastinal linfonodes (Peters et al., 2001, 2004).

We have provided the first biochemical and structural analysis of POPMt together with some in vitro murine macrophages immunomodulatory response elicited by the intact protease. More studies must be carried out to determining if native POMt has a role in $M$. tuberculosis infection. If ratified, POPMt could be proposed as new target for the development of anti-mycobacteria drugs. 


\section{ETHICS STATEMENT}

This study was carried out in accordance with the recommendations of Comissão de Ética no Uso de Animais da Universidade de Brasília. The protocol was approved by Comissão de Ética no Uso de Animais da Universidade de Brasília.

\section{AUTHOR CONTRIBUTIONS}

Conceived and designed the experiments: BP, FM, DN, KM, IB, and JS. Performed the experiments: BP, FM, AC, DN, KM, and FV Analyzed data: BP, FM, DN, HdA, KM, and IB. Contributed reagents/materials/analysis tools: DN, AA, IB, and JS. Wrote the paper: BP, FM, AC, DN, HdA, KM, IB, and JS.

\section{FUNDING}

This work was supported by CAPES-COFECUB $\mathrm{N}^{\circ} 723 / 11$, CNPq, MCTI/CNPq/FNDCT/PRO-CENTRO-OESTE 407730/ 2013-3, FAPDF, FINEP.

\section{REFERENCES}

Altschul, S. F., Madden, T. L., Schäffer, A. A., Zhang, J., Zhang, Z., Miller, W., et al. (1997). Gapped BLAST and PSI-BLAST: a new generation of protein database search programs. Nucleic Acids Res. 25, 3389-3402. doi: 10.1093/nar/25.17.3389

Bakker, A. V., Jung, S., Spencer, R. W., Vinick, F. J., and Faraci, W. S. (1990). Slow tight-binding inhibition of prolyl endopeptidase by benzyloxycarbonyl-prolylprolinal. Biochem. J. 271, 559-562. doi: 10.1042/bj2710559

Balcewicz-Sablinska, M. K., Keane, J., Kornfeld, H., and Remold, H. G. (1998). Pathogenic Mycobacterium tuberculosis evades apoptosis of host macrophages by release of TNF-R2, resulting in inactivation of TNF-alpha. J. Immunol. 161, 2636-2641.

Bastos, I. M., Grellier, P., Martins, N. F., Cadavid-Restrepo, G., de Souza-Ault, M. R., Augustyns, K., et al. (2005). Molecular, functional and structural properties of the prolyl oligopeptidase of Trypanosoma cruzi (POP Tc80), which is required for parasite entry into mammalian cells. Biochem. J. 388, 29-38. doi: 10.1042/BJ20041049

Bastos, I. M., Motta, F. N., Charneau, S., Santana, J. M., Dubost, L., Augustyns, K., et al. (2010). Prolyl oligopeptidase of Trypanosoma brucei hydrolyzes native collagen, peptide hormones and is active in the plasma of infected mice. Microbes Infect. 12, 457-466. doi: 10.1016/j.micinf.2010. 02.007

Berendsen, H. J. C., Postma, J. P. M., Van Gunsteren, W. F., and Hermans, J. (1981). "Interaction models for water in relation to protein hydration," in Intermolecular Forces, ed. B. Pullman (Dordrecht: Springer Science+Business Media), 331-342. doi: 10.1007/978-94-015-7658-1_21

Berman, H. M., Westbrook, J., Feng, Z., Gilliland, G., Bhat, T. N., Weissig, H., et al. (2000). The protein data bank. Nucleic Acids Res. 28, 235-242. doi: 10.1093/nar/ 28.1.235

Chackerian, A. A., Alt, J. M., Perera, T. V., Dascher, C. C., and Behar, S. M. (2002). Dissemination of Mycobacterium tuberculosis is influenced by host factors and precedes the initiation of T-cell immunity. Infect. Immun. 70, 4501-4509. doi: 10.1128/IAI.70.8.4501-4509.2002

Clay, H., Volkman, H. E., and Ramakrishnan, L. (2008). Tumor necrosis factor signaling mediates resistance to mycobacteria by inhibiting bacterial growth and macrophage death. Immunity 29, 283-294. doi: 10.1016/j.immuni.2008. 06.011

\section{ACKNOWLEDGMENTS}

We thank José Vitor da Silva for technical help at the BSL3 facility at the Laboratório Central de Saúde Pública do Distrito Federal - Brasília - DF (Lacen - DF). The MDs research was made possible thanks to the computing resources provided by the Center for Scientific Computing (GridUNESP), Universidade Estadual Paulista (UNESP). The results presented in this text were produced by Brina Portugal and coworkers during her thesis held at the University of Brasília. Portugal, B. (2014) Caracterização bioquímica, dinâmica molecular e propriedades imunomoduladoras da prolil oligopeptidase de M. tuberculosis [doctoral thesis]. [Brasília (DF)]: Universidade de Brasília. http: //repositorio.unb.br/handle/10482/16840.

\section{SUPPLEMENTARY MATERIAL}

The Supplementary Material for this article can be found online at: http://journal.frontiersin.org/article/10.3389/fmicb. 2017.00155/full\#supplementary-material

FIGURE 1 | Plots from molecular dynamics of POPMt. (A) Radius of gyration versus time plot. (B) Hydrogen bonds versus time plot. (C) Solvent accessible area versus time plot.

Cooper, A. M., and Torrado, E. (2012). Protection versus pathology in tuberculosis: recent insights. Curr. Opin. Immunol. 24, 431-437. doi: 10.1016/j.coi.2012. 04.008

Cornish-Bowden, A. (1976). Principles of Enzyme Kinetics. Amsterdam: Elsevier Ltd.

Correa, A. F., Bailão, A. M., Bastos, I. M., Orme, I. M., Soares, C. M., Kipnis, A., et al. (2014). The endothelin system has a significant role in the pathogenesis and progression of Mycobacterium tuberculosis infection. Infect. Immun. 82, 5154-5165. doi: 10.1128/IAI.02304- 14

Darden, T., York, D., and Pedersen, L. (1993). Particle mesh Ewald: an N.log(N) method for Ewald sums in large systems. J. Chem. Phys. 98, 10089-10092. doi: 10.1063/1.464397

de Almeida, H., Bastos, I. M. D., Ribeiro, B. M., Maigret, B., and Santana, J. M. (2013). New binding site conformations of the dengue virus NS3 protease accessed by molecular dynamics simulation. PLoS ONE 8:e72402. doi: 10.1371/ journal.pone.0072402

Elkington, P. T., Ugarte-Gil, C. A., and Friedland, J. S. (2011). Matrix metalloproteinases in tuberculosis. Eur. Respir. J. 38, 456-464. doi: 10.1183/ 09031936.00015411

Essmann, U., Perera, L., Berkowitz, M. L., Darden, T., Lee, H., and Pedersen, L. G. (1995). A smooth particle mesh Ewald method. J. Chem. Phys. 103, 8577-8593. doi: $10.1063 / 1.470117$

Eswar, N., Webb, B., Marti-Renom, M. A., Madhusudhan, M. S., Eramian, D., Shen, M.-Y., et al. (2006). Comparative protein structure modeling using Modeller. Curr. Protoc. Bioinformatics Chapter 5: Unit 5.6. doi: 10.1002/0471250953. bi0506s 15

Fajtová, P., Štefanić, S., Hradilek, M., Dvoøák, J., Vondrášek, J., Jílková, A., et al. (2015). Prolyl oligopeptidase from the blood fluke Schistosoma mansoni: from functional analysis to anti-schistosomal inhibitors. PLoS Negl. Trop. Dis. 9:e0003827. doi: 10.1371/journal.pntd. 0003827

Fogel, N. (2015). Tuberculosis: a disease without boundaries. Tuberculosis (Edinb). 95, 527-531. doi: 10.1016/j.tube.2015.05.017

Gaggar, A., Rowe, S. M., Matthew, H., and Blalock, J. E. (2010). Proline-glycineproline (PGP) and high mobility group box protein-1 (HMGB1): potential mediators of cystic fibrosis airway inflammation. Open Respir. Med. J. 4, 32-38. doi: $10.2174 / 1874306401004020032$ 
Galimi, R. (2011). Extrapulmonary tuberculosis: tuberculous meningitis new developments. Eur. Rev. Med. Pharmacol. Sci. 15, 365-386.

Gerszten, R. E., Garcia-Zepeda, E. A., Lim, Y.-C., Yoshida, M., Ding, H. A., Gimbrone, M. A. Jr., et al. (1999). MCP-1 and IL-8 trigger firm adhesion of monocytes to vascular endothelium under flow conditions. Nature 398, 718-723. doi: $10.1038 / 19546$

Goldberg, M. F., Saini, N. K., and Porcelli, S. A. (2014). Evasion of innate and adaptive immunity by Mycobacterium tuberculosis. Microbiol. Spectr. 2. doi: 10.1128/microbiolspec.MGM2-0005-2013

Grellier, P., Vendeville, S., Joyeau, R., Bastos, I. M., Drobecq, H., Frappier, F., et al. (2001). Trypanosoma cruzi prolyl oligopeptidase Tc80 is involved in nonphagocytic mammalian cell invasion by trypomastigotes. J. Biol. Chem. 276, 47078-47086. doi: 10.1074/jbc.M106017200

Hess, B., Bekker, H., Berendsen, H. J. C., and Fraaije, J. G. E. M. (1997). LINCS: a linear constraint solver for molecular simulations. J. Comput. Chem. 18, 14631472. doi: 10.1002/(SICI)1096-987X(199709)18:12<1463::AID-JCC4<3.3.CO; 2-L

Hess, B., Kutzner, C., Van Der Spoel, D., and Lindahl, E. (2008). GRGMACS 4: algorithms for highly efficient, load-balanced, and scalable molecular simulation. J. Chem. Theory Comput. 4, 435-447. doi: 10.1021/ct700301q

Holt, P. G., and Schon-Hegrad, M. A. (1987). Localization of T cells, macrophages and dendritic cells in rat respiratory tract tissue: implications for immune function studies. Immunology 62, 349-356.

Jayaraman, P., Sada-Ovalle, I., Beladi, S., Anderson, A. C., Dardalhon, V., Hotta, C., et al. (2010). Tim3 binding to galectin-9 stimulates antimicrobial immunity. J. Exp. Med. 207, 2343-2354. doi: 10.1084/jem.20100687

Jayaraman, P., Sada-Ovalle, I., Nishimura, T., Anderson, A. C., Kuchroo, V. K., Remold, H. G., et al. (2013). IL-1 $\beta$ promotes antimicrobial immunity in macrophages by regulating TNFR signaling and caspase-3 activation. J. Immunol. 190, 4196-4204. doi: 10.4049/jimmunol.1202688

Joyeau, R., Maoulida, C., Guillet, C., Frappier, F., Teixeira, A. R., Schrével, J., et al. (2000). Synthesis and activity of pyrrolidinyl- and thiazolidinyl-dipeptide derivatives as inhibitors of the Tc80 prolyl oligopeptidase from Trypanosoma cruzi. Eur. J. Med. Chem. 35, 257-266. doi: 10.1016/S0223-5234(00)00118-5

Juffermans, N. P., Dekkers, P. E., Peppelenbosch, M. P., Speelman, P., van Deventer, S. J., and van Der Poll, T. (2000). Expression of the chemokine receptors CXCR1 and CXCR2 on granulocytes in human endotoxemia and tuberculosis: involvement of the p38 mitogen-activated protein kinase pathway. J. Infect. Dis. 182, 888-894. doi: 10.1086/315750

Kabashima, T., Fujii, M., Meng, Y., Ito, K., and Yoshimoto, T. (1998). Prolyl endopeptidase from Sphingomonas capsulata: isolation and characterization of the enzyme and nucleotide sequence of the gene. Arch. Biochem. Biophys. 358, 141-148. doi: 10.1006/abbi.1998.0836

Kanatani, A., Yoshimoto, T., Kitazono, A., Kokubo, T., and Tsuru, D. (1993). Prolyl endopeptidase from Aeromonas hydrophila: cloning, sequencing, and expression of the enzyme gene, and characterization of the expressed enzyme. J. Biochem. 113, 790-796.

Kaushik, S., and Sowdhamini, R. (2011). Structural analysis of prolyl oligopeptidases using molecular docking and dynamics: insights into conformational changes and ligand binding. PLoS ONE 6:e26251. doi: 10.1371/journal.pone.0026251

Koida, M., and Walter, R. (1976). Post-proline cleaving enzyme. Purification of this endopeptidase by affinity chromatography. J. Biol. Chem 251, 7593-7599.

Korb, V. C., Chuturgoon, A. A., and Moodley, D. (2016). Mycobacterium tuberculosis: manipulator of protective immunity. Int. J. Mol. Sci. 17:E131. doi: $10.3390 / \mathrm{ijms} 17030131$

Ladel, C. H., Blum, C., Dreher, A., Reifenberg, K., Kopf, M., and Kaufmann, S. H. (1997). Lethal tuberculosis in interleukin-6-deficient mutant mice. Infect. Immun. 65, 4843-4849.

Lakowicz, J. R. (2004). Principles of Fluorescence Spectroscopy. New York, NY: Springer Science+Business Media.

Lebrun, I., Marques-Porto, R., Pereira, A. S., Pereira, A., and Perpetuo, E. A. (2009). Bacterial toxins: an overview on bacterial proteases and their action as virulence factors. Mini Rev. Med. Chem. 9, 820-828. doi: 10.2174/138955709788 452603

Lun, S., and Bishai, W. R. (2007). Characterization of a novel cell wall-anchored protein with carboxylesterase activity required for virulence in Mycobacterium tuberculosis. J. Biol. Chem. 282, 18348-18356. doi: 10.1074/jbc.M700035200
Maes, M., Goossens, F., Lin, A., De Meester, I., Van Gastel, A., and Scharpé, S. (1998). Effects of psychological stress on serum prolyl endopeptidase and dipeptidyl peptidase IV activity in humans: higher serum prolyl endopeptidase activity is related to stress-induced anxiety. Psychoneuroendocrinology 23, 485-495. doi: 10.1016/S0306-4530(98)00020-1

Maes, M., Goossens, F., Scharpé, S., Calabrese, J., Desnyder, R., and Meltzer, H. Y. (1995). Alterations in plasma prolyl endopeptidase activity in depression, mania, and schizophrenia: effects of antidepressants, mood stabilizers, and antipsychotic drugs. Psychiatry Res. 58, 217-225. doi: 10.1016/0165-1781(95) 02698-V

Maes, M., Monteleone, P., Bencivenga, R., Goossens, F., Maj, M., Van West, D., et al. (2001). Lower serum activity of prolyl endopeptidase in anorexia and bulimia nervosa. Psychoneuroendocrinology 26, 17-26. doi: 10.1016/S03064530(00)00032-9

Mantle, D., Falkous, G., Ishiura, S., Blanchard, P. J., and Perry, E. K. (1996). Comparison of proline endopeptidase activity in brain tissue from normal cases and cases with Alzheimer's disease, Lewy body dementia, Parkinson's disease and Huntington's disease. Clin. Chim. Acta 249, 129-139. doi: 10.1016/00098981(96)06282-1

Martinez, A. N., Mehra, S., and Kaushal, D. (2013). Role of interleukin 6 in innate immunity to Mycobacterium tuberculosis infection. J. Infect. Dis. 207, 1253-1261. doi: 10.1093/infdis/jit037

Master, S. S., Rampini, S. K., Davis, A. S., Keller, C., Ehlers, S., Springer, B., et al. (2008). Mycobacterium tuberculosis prevents inflammasome activation. Cell Host Microbe 3, 224-232. doi: 10.1016/j.chom.2008.03.003

Mayer-Barber, K. D., Barber, D. L., Shenderov, K., White, S. D., Wilson, M. S., Cheever, A., et al. (2010). Caspase-1 independent IL-1beta production is critical for host resistance to Mycobacterium tuberculosis and does not require TLR signaling in vivo. J. Immunol. 184, 3326-3330. doi: 10.4049/jimmunol.0904189

Mihret, A., Bekele, Y., Bobosha, K., Kidd, M., Aseffa, A., Howe, R., et al. (2013). Plasma cytokines and chemokines differentiate between active disease and nonactive tuberculosis infection. J. Infect. 66, 357-365. doi: 10.1016/j.jinf.2012.11. 005

Morty, R. E., Shih, A. Y., Fülöp, V., and Andrews, N. W. (2005). Identification of the reactive cysteine residues in oligopeptidase B from Trypanosoma brucei. FEBS Lett. 579, 2191-2196. doi: 10.1016/j.febslet.2005.03.014

Motta, F. N., Bastos, I. M., Faudry, E., Ebel, C., Lima, M. M., Neves, D., et al. (2012). The Trypanosoma cruzi virulence factor oligopeptidase B (OPBTc) assembles into an active and stable dimer. PLoS ONE 7:e30431. doi: 10.1371/journal.pone. 0030431

Mukherjee, S., Saha, B., and Das, A. K. (2009). Differential chemical and thermal unfolding pattern of Rv3588c and Rv1284 of Mycobacterium tuberculosis A comparison by fluorescence and circular dichroism spectroscopy. Biophys. Chem. 141, 94-104. doi: 10.1016/j.bpc.2009.01.002

Nagabhushanam, V., Solache, A., Ting, L. M., Escaron, C. J., Zhang, J. Y., and Ernst, J. D. (2003). Innate inhibition of adaptive immunity: Mycobacterium tuberculosis-induced IL-6 inhibits macrophage responses to IFN-gamma. J. Immunol. 171, 4750-4757. doi: 10.4049/jimmunol.171.9.4750

O’Reilly, P. J., Hardison, M. T., Jackson, P. L., Xu, X., Snelgrove, R. J., Gaggar, A., et al. (2009). Neutrophils contain prolyl endopeptidase and generate the chemotactic peptide, PGP, from collagen. J. Neuroimmunol. 217, 51-54. doi: 10.1016/j.jneuroim.2009.09.020

Orme, I. M., and Cooper, A. M. (1999). Cytokine/chemokine cascades in immunity to tuberculosis. Immunol. Today 20, 307-312. doi: 10.1016/S0167-5699(98) 01438-8

Peters, W., Cyster, J. G., Mack, M., Schlondorff, D., Wolf, A. J., Ernst, J. D., et al. (2004). CCR2-dependent trafficking of F4/80dim macrophages and $\mathrm{CD} 11 \mathrm{cdim} /$ intermediate dendritic cells is crucial for $\mathrm{T}$ cell recruitment to lungs infected with Mycobacterium tuberculosis. J. Immunol. 172, 7647-7653. doi: 10.4049/jimmunol.172.12.7647

Peters, W., Scott, H. M., Chambers, H. F., Flynn, J. L., Charo, I. F., and Ernst, J. D. (2001). Chemokine receptor 2 serves an early and essential role in resistance to Mycobacterium tuberculosis. Proc. Natl. Acad. Sci. U.S.A. 98, 7958-7963. doi: 10.1073/pnas.131207398

Pokalsky, C., Wick, P., Harms, E., Lytle, F. E., and Van Etten, R. L. (1995). Fluorescence resolution of the intrinsic tryptophan residues of bovine protein tyrosyl phosphatase. J. Biol. Chem. 270, 3809-3815. doi: 10.1074/jbc.270.8. 3809 
Qiu, Y., Chen, J., Liao, H., Zhang, Y., Wang, H., Li, S., et al. (2012). Tim3-expressing CD4+ and CD8+ T cells in human tuberculosis (TB) exhibit polarized effector memory phenotypes and stronger anti-TB effector functions. PLoS Pathog. 8:e1002984. doi: 10.1371/journal.ppat.1002984

Raju, R. M., Unnikrishnan, M., Rubin, D. H. F., Krishnamoorthy, V., Kandror, O., Akopian, T. N., et al. (2012). Mycobacterium tuberculosis ClpP1 and ClpP2 function together in protein degradation and are required for viability in vitro and during infection. PLoS Pathog. 8:e1002511. doi: 10.1371/journal.ppat. 1002511

Rea, D., and Fülöp, V. (2006). Structure-function properties of prolyl oligopeptidase family enzymes. Cell Biochem. Biophys. 44, 349-365. doi: $10.1385 / \mathrm{CBB}: 44: 3: 349$

Reiley, W. W., Calayag, M. D., Wittmer, S. T., Huntington, J. L., Pearl, J. E., Fountain, J. J., et al. (2008). ESAT-6-specific CD4 T cell responses to aerosol Mycobacterium tuberculosis infection are initiated in the mediastinal lymph nodes. Proc. Natl. Acad. Sci. U.S.A. 105, 10961-10966. doi: 10.1073/pnas. 0801496105

Rengarajan, J., Murphy, E., Park, A., Krone, C. L., Hett, E. C., Bloom, B. R., et al. (2008). Mycobacterium tuberculosis Rv2224c modulates innate immune responses. Proc. Natl. Acad. Sci. U.S.A. 105, 264-269. doi: 10.1073/pnas. 0710601105

Richardson, J. S. (1981). The anatomy and taxonomy of protein structure. $A d v$. Protein Chem. 34, 167-339. doi: 10.1016/S0065-3233(08)60520-3

Roberts, D. M., Personne, Y., Ollinger, J., and Parish, T. (2013). Proteases in Mycobacterium tuberculosis pathogenesis: potential as drug targets. Future Microbiol. 8, 621-631. doi: 10.2217/fmb.13.25

Sada-Ovalle, I., Chávez-Galán, L., Torre-Bouscoulet, L., Nava-Gamiño, L., Barrera, L., Jayaraman, P., et al. (2012). The Tim3-galectin 9 pathway induces antibacterial activity in human macrophages infected with Mycobacterium tuberculosis. J. Immunol. 189, 5896-5902. doi: 10.4049/jimmunol.120 0990

Santana, J. M., Grellier, P., Schrével, J., and Teixeira, A. R. (1997). A Trypanosoma cruzi-secreted $80 \mathrm{kDa}$ proteinase with specificity for human collagen types I and IV. Biochem. J. 325(Pt 1), 129-137. doi: 10.1042/bj325 0129

Saunders, B. M., Frank, A. A., Orme, I. M., and Cooper, A. M. (2000). Interleukin6 induces early gamma interferon production in the infected lung but is not required for generation of specific immunity to Mycobacterium tuberculosis infection. Infect. Immun. 68, 3322-3326. doi: 10.1128/IAI.68.6.3322-3326. 2000

Sertl, K., Takemura, T., Tschachler, E., Ferrans, V. J., Kaliner, M. A., and Shevach, E. M. (1986). Dendritic cells with antigen-presenting capability reside in airway epithelium, lung parenchyma, and visceral pleura. J. Exp. Med. 163, 436-451. doi: 10.1084 /jem.163.2.436

Shan, L., Marti, T., Sollid, L. M., Gray, G. M., Khosla, C., Kabashima, T., et al. (2004). Comparative biochemical analysis of three bacterial prolyl endopeptidases: implications for coeliac sprue. Biochem. J. 383, 311-318. doi: 10.1042/BJ20040907

Shan, L., Mathews, I. I., and Khosla, C. (2005). Structural and mechanistic analysis of two prolyl endopeptidases: role of interdomain dynamics in catalysis and specificity. Proc. Natl. Acad. Sci. U.S.A. 102, 3599-3604. doi: 10.1073/pnas. 0408286102

Shan, L., Molberg, Ø., Parrot, I., Hausch, F., Filiz, F., Gray, G. M., et al. (2002). Structural basis for gluten intolerance in celiac sprue. Science 297, 2275-2279. doi: 10.1126/science.1074129

Sia, J. K., Georgieva, M., and Rengarajan, J. (2015). Innate immune defenses in human tuberculosis: an overview of the interactions between Mycobacterium tuberculosis and innate immune cells. J. Immunol. Res. 2015:747543. doi: 10. $1155 / 2015 / 747543$

Sodenkamp, J., Waetzig, G. H., Scheller, J., Seegert, D., Grötzinger, J., Rose-John, S., et al. (2012). Therapeutic targeting of interleukin-6 trans-signaling does not affect the outcome of experimental tuberculosis. Immunobiology 217, 996-1004. doi: 10.1016/j.imbio.2012.01.015

Solovic, I., Sester, M., Gomez-Reino, J. J., Rieder, H. L., Ehlers, S., Milburn, H. J., et al. (2010). The risk of tuberculosis related to tumour necrosis factor antagonist therapies: a TBNET consensus statement. Eur. Respir. J. 36, 1185-1206. doi: 10.1183/09031936.00028510
Szeltner, Z., Renner, V., and Polgár, L. (2000). The noncatalytic beta-propeller domain of prolyl oligopeptidase enhances the catalytic capability of the peptidase domain. J. Biol. Chem. 275, 15000-15005. doi: 10.1074/jbc. M000942200

Szwajcer-Dey, E., Rasmussen, J., Meldal, M., and Breddam, K. (1992). Prolinespecific endopeptidases from microbial sources: isolation of an enzyme from a Xanthomonas sp. J. Bacteriol. 174, 2454-2459. doi: 10.1128/jb.174.8.2454-2459. 1992

Tenorio-Laranga, J., Coret-Ferrer, F., Casanova-Estruch, B., Burgal, M., and García-Horsman, J. A. (2010). Prolyl oligopeptidase is inhibited in relapsingremitting multiple sclerosis. J. Neuroinflammation 7:23. doi: 10.1186/17422094-7-23

Tenorio-Laranga, J., Montoliu, C., Urios, A., Hernandez-Rabaza, V., Ahabrach, H., García-Horsman, J. A., et al. (2015). The expression levels of prolyl oligopeptidase responds not only to neuroinflammation but also to systemic inflammation upon liver failure in rat models and cirrhotic patients. J. Neuroinflammation 12:183. doi: 10.1186/s12974-0150404-7

Tenorio-Laranga, J., Peltonen, I., Keskitalo, S., Duran-Torres, G., Natarajan, R., Männistö, P. T., et al. (2013). Alteration of prolyl oligopeptidase and activated $\alpha$-2-macroglobulin in multiple sclerosis subtypes and in the clinically isolated syndrome. Biochem. Pharmacol. 85, 1783-1794. doi: 10.1016/j.bcp.2013. 04.018

Usuki, H., Uesugi, Y., Iwabuchi, M., and Hatanaka, T. (2009). Activation of oligopeptidase B from Streptomyces griseus by thiol-reacting reagents is independent of the single reactive cysteine residue. Biochim. Biophys. Acta 1794, 1673-1683. doi: 10.1016/j.bbapap.2009.07.024

Vandal, O. H., Pierini, L. M., Schnappinger, D., Nathan, C. F., and Ehrt, S. (2008). A membrane protein preserves intrabacterial $\mathrm{pH}$ in intraphagosomal Mycobacterium tuberculosis. Nat. Med. 14, 849-854. doi: 10.1038/nm. 1795

Vandal, O. H., Roberts, J. A., Odaira, T., Schnappinger, D., Nathan, C. F., and Ehrt, S. (2009). Acid-susceptible mutants of Mycobacterium tuberculosis share hypersusceptibility to cell wall and oxidative stress and to the host environment. J. Bacteriol. 191, 625-631. doi: 10.1128/JB.00932-08

Vendeville, S., Buisine, E., Williard, X., Schrevel, J., Grellier, P., Santana, J., et al. (1999). Identification of inhibitors of an $80 \mathrm{kDa}$ protease from Trypanosoma cruzi through the screening of a combinatorial peptide library. Chem. Pharm. Bull. 47, 194-198. doi: 10.1248/cpb.47.194

Wells, J. M., Gaggar, A., and Blalock, J. E. (2015). MMP generated matrikines. Matrix Biol. 4, 122-129. doi: 10.1016/j.matbio.2015.01.016

WHO (2015). Global Tuberculosis Report. Available at: http://www.who.int/tb/publications/global_report/en/

Wilk, S., and Orlowski, M. (1983). Inhibition of rabbit brain prolyl endopeptidase by n-benzyloxycarbonyl-prolyl-prolinal, a transition state aldehyde inhibitor. J. Neurochem. 41, 69-75. doi: 10.1111/j.1471-4159.1983. tb11815.x

Williams, R. S., and Harwood, A. J. (2000). Lithium therapy and signal transduction. Trends Pharmacol. Sci. 21, 61-64. doi: 10.1016/S0165-6147(99) 01428-5

Williams, R. S. B., Eames, M., Ryves, W. J., Viggars, J., and Harwood, A. J. (1999). Loss of a prolyl oligopeptidase confers resistance to lithium by elevation of inositol $(1,4,5)$ trisphosphate. EMBO J. 18, 2734-2745. doi: 10.1093/emboj/18. 10.2734

Wolf, A. J., Desvignes, L., Linas, B., Banaiee, N., Tamura, T., Takatsu, K., et al. (2008). Initiation of the adaptive immune response to Mycobacterium tuberculosis depends on antigen production in the local lymph node, not the lungs. J. Exp. Med. 205, 105-115. doi: 10.1084/jem.20 071367

Yoshimoto, T., Kado, K., Matsubara, F., Koriyama, N., Kaneto, H., and Tsura, D. (1987). Specific inhibitors for prolyl endopeptidase and their anti-amnesic effect. J. Pharmacobiodyn. 10, 730-735. doi: 10.1248/bpb1978. 10.730

Yoshimoto, T., Kanatani, A., Shimoda, T., Inaoka, T., Kokubo, T., and Tsuru, D. (1991). Prolyl endopeptidase from Flavobacterium meningosepticum: cloning and sequencing of the enzyme gene1. J. Biochem. 110, $873-878$. 
Yoshimoto, T., Sattar, A. K., Hirose, W., and Tsuru, D. (1988). Studies on prolyl endopeptidase from shakashimeji (Lyophyllum cinerascens): purification and enzymatic properties. J. Biochem. 104, 622-627.

Yoshimoto, T., Walter, R., and Tsuru, D. (1980). Proline-specific endopeptidase from Flavobacterium. Purification and properties. J. Biol. Chem. 255, 47864792.

Yung-Chi, C., and Prusoff, W. H. (1973). Relationship between the inhibition constant (KI) and the concentration of inhibitor which causes 50 per cent inhibition (I50) of an enzymatic reaction. Biochem. Pharmacol. 22, 3099-3108. doi: 10.1016/0006-2952(73)90196-2

Zhao, N., Darby, C. M., Small, J., Bachovchin, D. A., Jiang, X., Burns-Huang, K. E., et al. (2015). Target-based screen against a periplasmic serine protease that regulates intrabacterial $\mathrm{pH}$ homeostasis in Mycobacterium tuberculosis. ACS Chem. Biol. 10, 364-371. doi: 10.1021/cb500746z
Zhao, Q. J., and Xie, J. P. (2011). Mycobacterium tuberculosis proteases and implications for new antibiotics against tuberculosis. Crit. Rev. Eukaryot. Gene Expr. 21, 347-361. doi: 10.1615/CritRevEukarGeneExpr.v21.i4.50

Conflict of Interest Statement: The authors declare that the research was conducted in the absence of any commercial or financial relationships that could be construed as a potential conflict of interest.

Copyright (C) 2017 Portugal, Motta, Correa, Nolasco, de Almeida, Magalhães, Atta, Vieira, Bastos and Santana. This is an open-access article distributed under the terms of the Creative Commons Attribution License (CC BY). The use, distribution or reproduction in other forums is permitted, provided the original author(s) or licensor are credited and that the original publication in this journal is cited, in accordance with accepted academic practice. No use, distribution or reproduction is permitted which does not comply with these terms. 